\title{
Dermatology Free from Ointments
}

\section{Masatoshi Deguchi*}

Department of Dermatology, Shiogama City Hospital, Japan

\section{Opinion}

In the dermatological treatment onsite various kinds of ointments have been applied to the lesional skin of the patients as a matter of routine, for the provision of antibacterial or antiviral activity at the locale, the promotion of anti-inflammatory effect, moisturization, emollient use, scavenging the necrotic tissue and debris from the surface of the skin ulcers as well as immunomodulation of the host immune cells at the locale, and as such, these types of medication have been employed for eczematous dermatitis, psoriasis, lichen planus, prurigo, erythema multiforme, bullous diseases and even for lymphoma of the skin. On the other hand, however, it has become increasingly accepted that these means of treatments have not sufficed to bring relief from the refractory skin diseases. Such serious disorders include the inexorably progressive skin cancers and the intractable inflammatory dermatoses.

Since last century, surgical resection has stood the test of time as golden standard of the curative therapy for malignant solid tumors of the skin; malignant melanoma [1,2], squamous cell carcinoma [3-5] and basal cell carcinoma [6,7] followed by the radiation treatment and / or the conventional chemotherapy according to conditions. In addition, the roles of the checkpoint inhibitors [8,9] and molecular target-based drugs [10-13] in the treatment of advanced stage melanoma are rapidly being established.

Another recent remarkable progress in dermatology concerns the development of the biologics for the treatment of psoriasis, palmoplantar pustulosis, atopic dermatitis in addition to urticaria. Novel insights into the immunopathogenesis of those diseases have led to the development of new effective therapies. Taking psoriasis as an example, the active components of the injected preparations are the antibodies against the cytokines responsible for the pathogenesis; anti-Interleukin (IL) 23 [14], -Il-23/-IL-12 [15], -IL-17 [16,17], -IL-17 receptor A [18], and -TNF [19-21], based on the understanding of the major role of IL-17producing helper $\mathrm{T}$ lymphocyte. The clinical effects of these biologics were investigated with overwhelmingly excellent results compared to the conventional topical therapies including ointments and phototherapies, and well-tolerated throughout the duration of treatments.

These new therapies have been produced by the recent major advances of immunology, and such multidisciplinary studies-based medications are now replacing the conventional ointments therapy, promising the paradigm shift on dermatological treatments.

\section{References}

1. Lens MB, Dawes M, Goodacre T (2002) Excision margins in the treatment of primary cutaneous melanoma: a systematic review of randomized controlled trials comparing narrow vs wide excision. Archives of Surgery 137(10): 1101-1105.

2. Haigh PI, DiFronzo LA, McCready DR (2003) Optimal excision margins for primary cutaneous melanoma: a systematic review and meta-analysis. Can J Surg 46(6): 419-426.

3. Motey R, Kersey P, Lawrence C (2002) Multiprofessional guidelines for the management of the patient with primary cutaneous squamous cell carcinoma. Br J Dermaatol 146(1): 18-25.

4. Cancer council Australia / Australian Cancer Network (2008) Clinical practice guide, Basal cell carcinoma, squamous cell carcinoma (and related lesions)-a guide to clinical management in Australia. Surgical treatment, Australia, pp. 51-54.

5. NCCN: Clinical practice guideline in oncology (2013) Basal cell and squamous cell skin cancers. 2: SCC-1-MS-25.

6. Thissen MR, Neumann MH, Schouten LJ (1999) A systematic review of treatment modalities for primary basal cell carcinomas. Arch Dermatol 135(10): 1177-1183. 
7. Bath FJ, Perkins W, Bong J, Williams HC (2007) Interventions for basal cell carcinoma of the skin. Cochrane Database Syst Rev (1): CD003412.

8. Topalian SL, Hodi FS, Brahmer JR, Gettinger SN, Smith DC, et al. (2012) Safety, activity, and immune correlates of anti-PD-1 antibody in cancer. N Engl J Med 366(26): 2443-2454.

9. Okazaki T, Chikuma S, Iwai Y, Fagarasan S, Honjo T (2013) A rheostat for immune responses: the unique properties of PD-1 and their advantages for clinical application. Nat Immunol 14(12): 1212-1218.

10. Robert C, Thomas L, Bondarenko I, O’Day S, Weber J, et al. (2011) Ipilimumab plus dacarbazine for previously untreated metastatic melanoma. N Engl J Med 364(26): 2517-2526.

11. Capman PB, Hauschild A, Robert C, Haanen JB, Ascierto P, et al. (2011) Improved survival with vemurafenib in melanoma with BRAF V600E mutation. N Engl J Med 364(26): 2507-2516.

12. Hauschild A, Grob JJ, Demidov LV, Jouary T, Gutzmer R, et al. (2012) Dabrafenib in BRAF-mutated metastatic melanoma: a multicenter openlabel, phase 3 randomised controlled trial. Lancet 380(9839): 358-365.

13. Flaherty K T, Robert C, Hersey P, Nathan P, Garbe C, et al. (2012) Improved survival with MEK inhibition in BRAF-mutated melanoma. N Engl J Med 367(2): 107-114.

14. Blauvelt A, Papp KA, Griffiths CEM, Randazzo B, Wasfi Y, et al (2017) Efficacy and safety of guselkumab, an anti-interleukin-23 monoclonal antibody, compared with adalimumab for the continuous treatment of patients with moderate to severe psoriasis: Results from the phase III, double-blinded, placebo-and active comparator-controlled VOYAGE 1 trial. J Am Acad Dermatol 76(3): 405-417.
15. Leonardi CL, Kimball AB, Papp KA, Yeilding N, Guzzo C, et al. (2008) Efficacy and safety of ustekinumab, a human interleukin-12 / 23 monoclonal antibody, in patients with psoriasis: 76-week results from a randomized, double-blind, placebo-controlled trial (PHOENIX 1). Lancet 371(9625): 1665-1674

16. Langley RG, Elewski BE, Lebwohl M, Reich K, Griffiths CE, et al. (2014) Secukinumab in plaque psoriasis-results of two phase 3 trials. N Engl J Med 371(4): 326-338.

17. Gordon KB, Blauvelt A, Papp KA, Langley RG, Luger T, et al. (2016) Phase 3 Trials of Ixekizumab in moderate-to-severe plaque psoriasis. $\mathrm{N}$ Engl J Med 375(4): 345-356.

18. Papp KA, Reich K, Paul C, Blauvelt A, Baran W, et al (2016) A prospective phase III, randomized, double-blind, placebo-controlled study of brodalumab in patients with moderate-to-severe plaque psoriasis. $\mathrm{Br} \mathrm{J}$ Dermatol 175(2): 273-286.

19. Menter A, Trying SK, Gordeon K, Kimball AB, Leonardi CL, et al. (2008) Adalimumab therapy for moderate to severe psoriasis: A randomized, controlled phase III trial. J Am Acad Dermatol 58(1): 106-115.

20. Reich K, Nestle FO, Papp K, Ortonne JP, Evans R, et al (2005) Infliximab induction and maintenance therapy for moderate-to-severe psoriasis: a phase III, multicenter, double-blind trial. Lancet 366(9494): 1367-1374.

21.Zalevsky J, Secher T, Ezhevsky SA, Janot L, Steed PM, et al. (2007) Dominant-negative inhibitors of soluble TNF attenuate experimental arthritis without suppressing innate immunity to infection. J Immunol 179(3): 1872-1883 